\title{
Influence of the Virginia Fanpetals Cultivation Method on Calorific Value, Content and Dynamics of Macronutrient Uptake
}

\author{
Ewa Możdżer ${ }^{1 *}$, Hanna Siwek², Małgorzata Włodarczyk², Marek Bury³ ${ }^{3}$ Teodor Kitczak ${ }^{1}$ \\ 1 WestPomeranian University ofTechnology in Szczecin, Departament of Environmetal Chemistry2, Department \\ of Agricultural Engineering, Department of Bioengineering3, ul. Słowackiego 17, 71-434 Szczecin, Poland \\ * Corresponding author's e-mail: emozdzer@zut.edu.pl
}

\begin{abstract}
A one-factor field experiment was carried out in 2016-2019 at the Experimental Station in Lipnik near Stargard. The aim of the study was the cultivation of Virginia fanpetals in two systems of sowing and planting, determining the impact of the cultivation system on the yield quantity, calorific value, moisture, content and dynamics of the macronutrient uptake by Virginia fanpetals, calculation of the relationship between the yield and NPK intake, calorific value and yield as well as the analytical moisture content. Studies have shown that the method of establishing the plantation (sowing, planting) did not have any significant impact on the calorific value of Sida. A statistical analysis indicated that the method of establishing the plantation (sowing, planting) did not have a significant impact on the formation of the nitrogen, phosphorus and potassium contents in the biomass, while it was significant for magnesium and sulfur. More macroelements was contained in the Virginia fanpetals biomass from sowing compared to planting. The total uptake of macronutrients by the Virginia fanpetals biomass was higher in the planting cultivation system. In the system of planting cultivation, in the first year of plantation operation, higher dynamics of the N, P, K, Mg and S uptake by the Virginia fanpetals biomass compared to the sowing system was found. A correlation analysis showed very high degree of correlation between the size of Virginia fanpetals biomass yield as well as the nitrogen and phosphorus uptake.
\end{abstract}

Keywords: virginia mallow, cultivation, biomass, calorific, value, content and uptake of macronutrients

\section{INTRODUCTION}

Biomass is one of the sources of renewable energy in Poland and the European Union. It is obtained from organic municipal waste, agricultural and forestry waste as well as the wood industry. The energy-efficient plant species include perennial grasses, perennials, shrubs and trees with a short production cycle ranging from a few to several years [Kowalczyk-Jusko 2009, Sapek and Sapek 2012, Borkowska et al. 2016]. The field crops of perennial plants that give biomass from wood (Salix spp.), semi-wood (Sida hermaphodrita Rusby) and straw (Miscanthus saccharflorus) can support the supply of the biomass for the energy purposes.

The fuels produced from the biomass are used in the production of heat or electricity. Its combustion is the most widespread so far, but an alternative way of obtaining the energy based on the biogas obtained from agricultural waste is rapidly developing [Jagustyn et al. 2011, Mółka et al. 2011, Biernat 2012, Borkowska et al. 2016]. In the European Union, $92 \%$ of biomass is intended for the production of heat and $7.0 \%$ for electricity [Janowicz 2006]. Reduction of the non-renewable energy resources, increase in the costs of their obtaining and processing, as well as the threat of energy changes contribute to the acquisition of new energy sources.

The EU Climate Package [17.12.2008] assumes that this year (2020) the member countries should achieve a $20 \%$ share of energy from renewable sources and a $10 \%$ share from liquid biofuels. At the same time, the energy demand should be reduced by $20 \%$ and greenhouse gas emissions by $20 \%$ [Wach 2007]. In the European Union, Poland is perceived as a country with 
great possibilities of biomass production for the energy purposes and biofuels. Estimates show that in Poland, between 1.0 and 4.3 million ha of arable land will be used for growing the crops for energy purposes and biofuels [Wiesenthal 2006, Van Valthuizen 2003, Kowalczyk-Juśko, 2017].

Virginia fanpetals, cultivated for energy purposes, should be harvested during the winter or after the first frosts. This is justified by the increase in lignin and decrease in the moisture content, which is caused by delayed harvest [Iqbal and Lewandowski 2014, Kisiel and Lewandowski 2017]. The disadvantage of growing Virginia fanpetals in the first year is that the biomass yield is too low to be economically viable [Anderson 2011, Zub and Brancourt-Hulmel 2010].

In addition to yield, calorific value, and moisture content, the content of macronutrients, e.g. $\mathrm{C}, \mathrm{N}, \mathrm{P}, \mathrm{K}, \mathrm{Mg}$ and $\mathrm{S}$, is important. Their quantity in the plants intended for biomass is influenced by the genetically determined plant features that are modified by the environmental conditions, i.e.: soil properties (abundance, $\mathrm{pH}$ ), atmospheric conditions prevailing during plant vegetation (precipitation), as well as agrotechnical treatments performed during vegetation [Kalembasa et al. 2006, Borkowska and Lipiński 2008, Borkowska et al. 2009, Borkowska et al. 2016].

The aim of the study was the cultivation of Virginia fanpetals in two systems of sowing and planting, determining the impact of the cultivation system on the yield quantity, calorific value, moisture, content and dynamics of the macronutrient uptake by Virginia fanpetals, calculation of the relationship between yield and the NPK uptake, calorific value and yield as well as the analytical moisture content.

\section{MATERIAL AND METHODS}

A one-factor field experiment was carried out in 2016-2018 at the Experimental Station in Lipnik near Stargard $\left(53^{\circ} 20^{\prime} 17.8^{\prime \prime} \mathrm{N}\right.$, $\left.14^{\circ} 57^{\prime} 40.8^{\prime \prime} \mathrm{E}\right)$. Before establishing the experiment, the chemical soil analyses were carried out, taken from three layers. The field on which the experiment was established, is characterized by brown, incomplete soil, developed of light dusty loamy sand, medium deeply padded with light clay. The soil belongs to the IVa bonitation class, a complex of agricultural usefulness - good rye.
In the soil samples, before the experiment was set up, the $\mathrm{pH}$, total content of $\mathrm{C}, \mathrm{N}, \mathrm{P}, \mathrm{K}, \mathrm{Ca}$, $\mathrm{Mg}, \mathrm{S}$ and available forms of $\mathrm{P}, \mathrm{K}$ and $\mathrm{Mg}$ were determined. The soil used for the tests was characterized by a neutral $\mathrm{pH}_{\mathrm{KCl}} 5.90-6.78$, total carbon content in the layer $0-30 \mathrm{~cm}$ was 9.30 , nitrogen -0.92 , phosphorus -0.45 , potassium -0.62 , calcium -0.78 , magnesium -0.90 and sulfur $0.15 \mathrm{~g} \cdot \mathrm{kg}^{-1} \mathrm{DM}$. The soil abundance in the available P (134 mg $\left.\cdot \mathrm{kg}^{-1} \mathrm{DM}\right), \mathrm{K}\left(120 \mathrm{mg} \cdot \mathrm{kg}^{-1} \mathrm{DM}\right)$ and $\mathrm{Mg}\left(39.8 \mathrm{mg} \cdot \mathrm{kg}^{-1} \mathrm{DM}\right)$ forms was average. The concentration of micronutrients, including some heavy metals, in the soil was within the limits of the natural content [Regulation of the Minister of the Environment Journal of Laws 2016, item1395].

The spring barley, harvested for grain, was the forecrop for Virginia fanpetals. After harvesting the forecrop, traditional method of mechanical soil cultivation was used (stubble cultivation, post-harvest crop cultivation and pre-winter plowing). In spring, before sowing and planting Virginia fanpetals, mineral fertilization was applied in the amount of $100 \mathrm{~kg} \mathrm{~N} \cdot \mathrm{ha}^{-1}, 80 \mathrm{~kg} \mathrm{P} \cdot \mathrm{ha}^{-}$ ${ }^{1}$ and $100 \mathrm{~kg} \mathrm{~K} \cdot \mathrm{ha}^{-1}$. The test plant was Virginia fanpetals, grown from sowing and planting. The seeds after conversion to $100 \%$ germination were sown in an amount of $3 \mathrm{~kg} \cdot \mathrm{ha}^{-1}$ with a row spacing of $45 \mathrm{~cm}$, a depth of approximately $1 \mathrm{~cm}$ applying a seed drill. Planting was carried out with a density of 4.4 pcs. per $1 \mathrm{~m}^{2}$. On all test objects, before the rows compaction, mechanical weeding was performed between rows. Weeding was unnecessary in the subsequent years of research. During the vegetation, the meteorological conditions and development phases of the test plant were observed. The area of one plot was $14 \mathrm{~m}^{2}$. Each experimental object was carried out in four replicates.

During the experiment (2016-2018), in order to determine the yield, moisture content, calorific value and chemical properties of the test plant, once a year in winter, Virginia fanpetals (N, P, $\mathrm{K}, \mathrm{Mg}$ and $\mathrm{S}$ ) were harvested from two systems: planting and sowing.

\section{ANALYTICAL METHODS}

After harvesting, the following items were determined in the Virginia fanpetals biomass: moisture content by means of the drying and weighing method, heat of combustion of dry 
biomass in the IKA C 2000 calorimeter (according to PN-81/G-04513) based on the isoperibolic method. The calorific value of the test plant was then calculated. Dry biomass yield $\left(\mathrm{Mg} \cdot \mathrm{ha}^{-1}\right)$ was determined on the basis of fresh biomass yield from individual plots and its moisture content (PN 8/G-04511). The nitrogen and sulfur content were determined on a Coestech CNS elemental analyzer, phosphorus by means of Barton colorimetric method, potassium and magnesium by atomic absorption spectrometry on a Perkin Elmer AAS 300 spectrometer. The stock solution was obtained after wet mineralization of plant material in a mixture of perchloric(VII) acid and nitrogen $(\mathrm{V})$ acid in a ratio of $3: 1$. The uptake of individual components in subsequent years was calculated as the product of the content of a given element in the biomass of Virginia fanpetals and the yield. The test results were statistically compiled according to the ANALWAR 5.3 program. For significant differences, the Tukey test was applied with a significance level of $p=0.05$. Then, the Pearson linear correlation coefficient $r$ between the yield and N, P and K uptake, between calorific value and yield as well as calorific value and moisture content, were calculated. The significance of the correlation coefficient was tested using the Student's t-test. The yield and content of some macronutrients contained in the Virginia fanpetals biomass were published in a monograph by Bury et al. [2019].

\section{RESULTAL AND DISCUSION}

The assessment of the obtained Virginia fanpetals biomass yield showed that it was significantly dependent on the method of establishing the crop and the period of use. In the first year, the biomass yield was low, but significantly higher by $135.7 \%$ on the objects with Virginia fanpetals planted from seedlings. In the years of the full use, the Virginia fanpetals biomass yields, compared to the year in which the plantation was established, were about nine times larger and significantly larger on the objects cultivated from seedlings. In 2017 , this difference was $11.3 \%$, and in $2018-22.2 \%$. There was a tendency to increase the biomass yield in the third year of use by $3.50 \%$ despite the fact that the sum of precipitation that year (compared to 2017) was almost $50 \%$ lower at higher average air temperatures. The area of energy crops in Europe is smaller compared to other agricultural crops [Lewandowski et al. 2016]. One of the most important reasons is the high cost of establishing a plantation and the lack of a biomass market [Bocqueho et al. 2010, Witzel et al. 2016].

The Virginia fanpetals biomass was characterized by a low content of analytical moisture $\left(\mathrm{W}_{\mathrm{a}}\right)$ - fig. 1. Regardless of the method of establishing the plantation, the $\mathrm{W}_{\mathrm{a}}$ content in the biomass of Virginia fanpetals was oscillating between $4.60 \%$ and $7.30 \%$. It has been noted that the factors having a significant influence on the analytical moisture content are the plantation age and atmospheric conditions prevailing during the growing season. The moisture content $\left(\mathrm{W}_{\mathrm{a}}\right)$ of the combusted material has a significant effect on the biomass energy properties. The lowest moisture content was characteristic of the Virginia fanpetals biomass in the second year of plantation (2017), and in the remaining years (in 2016 and 2018), it remained at a similar level. No significant influence of the plantation establishment method on the value of analytical moisture content of Virginia fanpetals biomass was found. The average moisture content of biomass from three years of plantation operation was $6.20 \%$.

The date of the Virginia fanpetals harvesting should be adapted to the manner of its use, which was confirmed by the authors' own research. Cosentino et al. [2018] and Lewandowski and Schmidt [2006], indicate that Virginia fanpetals

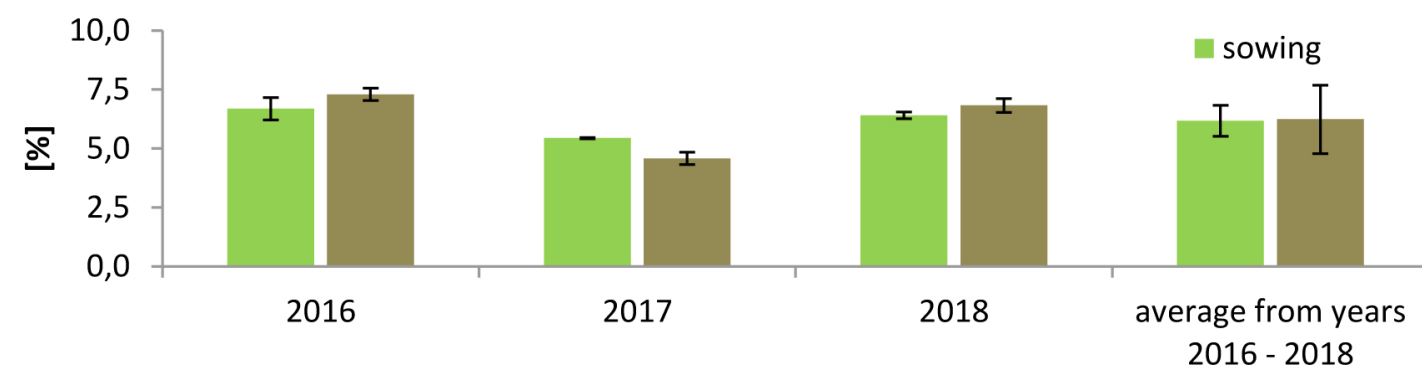

Fig. 1. Analytical moisture of Virginia fanpetals biomass. Source: Bury et al. [2019] 
is a perennial plant; therefore, it requires a small amount of fertilizers and plant protection products compared to annual plants [Artyszak 2016]. The advantage of Virginia fanpetals is low biomass humidity during harvest (16-28\%) and that no specialized equipment is required for harvesting.

The data contained in Table 1 indicate that: calorific value of Virginia fanpetals was ranged from 16.04 to $17.53 \mathrm{~kJ} \cdot \mathrm{kg}^{-1}$. No impact of the plantation establishment method on the calorific value was found. However, there was a significant increase in the calorific value of the Virginia fanpetals biomass between years. The highest calorific value was obtained in the third year of plantation from sowing $17.53 \mathrm{~kJ} \cdot \mathrm{kg}^{-1}$. It was $9.29 \%$ higher than in the first year (2016). The average calorific value of the Virginia fanpetals biomass from three years was higher by $4.37 \%$ when establishing a plantation from sowing compared to planting. In the conducted tests, the calorific value of the test plant biomass from sowing and planting was on average over three years $\left(16.68 \mathrm{~kJ} \cdot \mathrm{kg}^{-1}\right)$, which confirms the research by Artyszka [2016], Gajewskiego [2016],

Table 1. Calorific value of the biomass yield of Virginia fanpetals cultivated from sowing and planting and harvested in winter in years 2016-2018 [Bury et al. 2019]

\begin{tabular}{|c|c|c|c|}
\hline \multirow{2}{*}{ Crop years } & \multicolumn{2}{|c|}{$\begin{array}{c}\text { Plantation establishment } \\
\text { system }\end{array}$} & \multirow{2}{*}{ Mean } \\
\cline { 2 - 3 } & sowing & planting & \\
\hline 2016 & 16.04 & 16.38 & $\mathbf{1 6 . 2 1}$ \\
\hline 2017 & 16.53 & 16.19 & $\mathbf{1 6 . 3 6}$ \\
\hline 2018 & 17.53 & 17.46 & $\mathbf{1 7 . 4 9}$ \\
\hline Mean & $\mathbf{1 6 . 7}$ & $\mathbf{1 6 . 0}$ & $\mathbf{1 6 . 6 8}$ \\
\hline LSD $_{0.05}$ & $\mathbf{0 . 2 3}$ & $\mathbf{0 . 7 0}$ & $\mathbf{0 . 3 7}$ \\
\hline
\end{tabular}

Kacprzaka et al. [2012] who reported the values between 13.0 and $17.0 \mathrm{KJ} \cdot \mathrm{kg}^{-1}$.

Carbon has the highest percentage in the dry biomass of Virginia fanpetals. Its average share in biomass is about $36 \%$. An analysis of other macronutrients indicates that only for nitrogen, its average biomass share was greater than one percent. The percentage share in the biomass of other nutrients did not exceed $1 \%$ and they could be lined up in the following order: $\mathrm{K}(0.13 \%)$, $\mathrm{Mg}(0.70 \%), \mathrm{S}(0.10 \%), \mathrm{P}(0.05 \%)$ (Figure 2). The method of the plantation establishing did not affect the average percent share of the analyzed elements in the Virginia fanpetals biomass. The determining factors were the age of the plantation, weather conditions and lack of fertilization during the experiment. Fertilization was applied only in the year of the plantation establishment, for which the majority of components obtained a higher percent share in the biomass. Carbon was the least sensitive to the lack of fertilization, its per cent share in biomass during the three years was at a similar level of $36.6 \%$.

Too high or too low content of macronutrients in arable crops reduces their quality reduction for industrial processing. It also indicates the dynamics of the nutrients transition from soils to plants [Stanisławska-Glubiak and Korzeniowska 2007]. Virginia fanpetals grown from sowing and planting in 2016 contained the most nitrogen, phosphorus, potassium, magnesium and sulfur (Tabele 2).

The content of nitrogen in the biomass of Virginia fanpetals ranged from 12.59 to $23.30 \mathrm{~g} \cdot \mathrm{kg}^{-1} \mathrm{DM}$. The test plants harvested in the first year of experiment were characterized by its highest content. Regardless of how the plantation was set up, its concentration ranged from 22.55 to $23.30 \mathrm{~g} \cdot \mathrm{kg}^{-1} \mathrm{DM}$ (Table 3 ). In subsequent years, a downward trend of this element was noted. In the
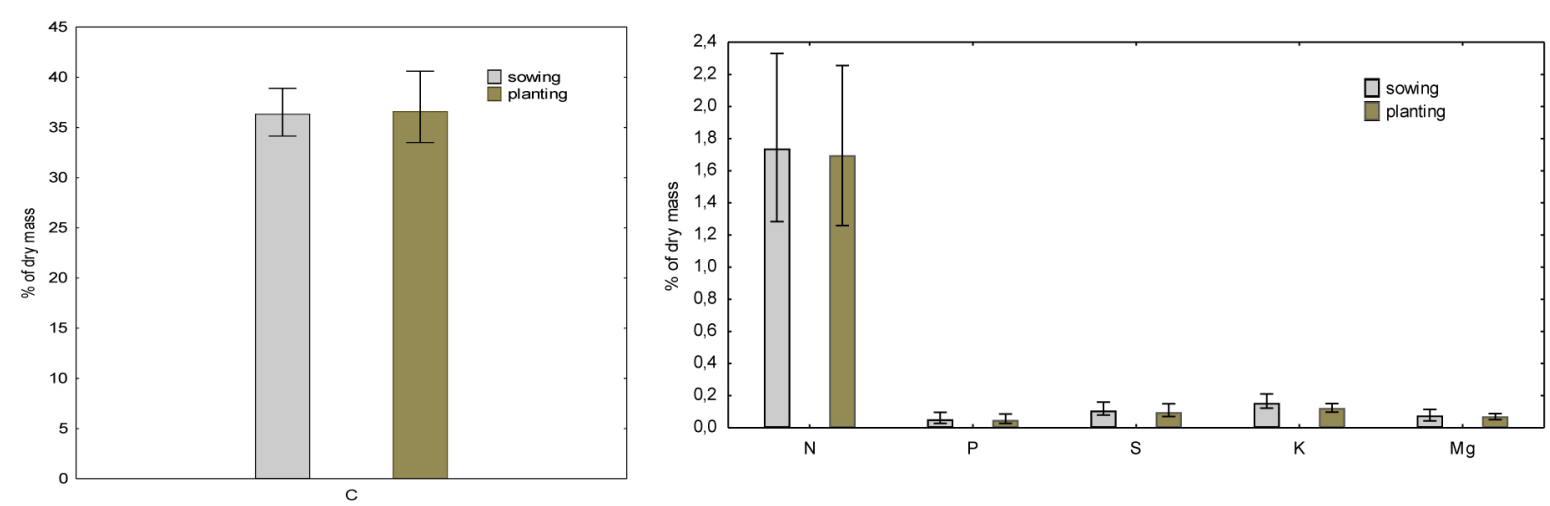

Fig. 2. Average percentage ( \pm maximum and minimum value) of analyzed nutrients in dry biomass

[Bury et al. 2019] 
biomass of Virginia fanpetals obtained from sowing and planting, the amount of nitrogen determined remained at an average level of $15.88 \mathrm{~g} \cdot \mathrm{kg}^{-}$ ${ }^{1}$ in the second year and $12.94 \mathrm{~g} \cdot \mathrm{kg}^{-1} \mathrm{DM}$ in the third year of experiment. It is the nitrogen content higher by $44.2 \%$ and $76.9 \%$, respectively, in relation to the nitrogen obtained in the biomass of the test plant in 2016. A statistical analysis showed a negligible effect of the plantation establishment method on the nitrogen content in the Virginia fanpetals biomass. Significant differences were found between the first, second and third year of running the plantation for the Virginia fanpetals biomass grown from sowing and planting.

The average phosphorus content in the Virginia fanpetals biomass in individual years in both the sowing and planting systems was similar. Regardless of how the plantation was established, the highest phosphorus content was recorded in the first year of plantation establishment. In subsequent years, there was a tendency for the content of the analyzed element to decrease in the Virginia fanpetals biomass compared to 2016; the amount of phosphorus determined in the second year of research was lower by $70.1 \%$, and in the third year by $66.3 \%$. No significant influence of the plantation establishment method on the phosphorus content in the Virginia fanpetals biomass was found (Table 2).

The analysis of the potassium and magnesium content in the test plant biomass showed a great variation. The potassium content ranged from 0.99 to $2.11 \mathrm{~g} \cdot \mathrm{kg}^{-1} \mathrm{DM}$ and mainly depended on the year, in which the harvest was made. The highest potassium content was obtained in the first year of plantation in the biomass of Virginia fanpetals grown from sowing, and less by $39.7 \%$ from planting. The plantation establishment system did not have any significant impact on the content of potassium in the biomass of Virginia fanpetals, except for the first year. In subsequent years, a decrease in the content of the analyzed

Table 2. General content of N, P, K, Mg and S in Virginia fanpetals biomass in years 2016-2018 $\left[\mathrm{g} \cdot \mathrm{kg}^{-1} \mathrm{DM}\right]$

\begin{tabular}{|c|c|c|c|c|c|}
\hline \multirow{3}{*}{ Crop years } & \multicolumn{4}{|c|}{ Plantation establishment system } & \multirow{3}{*}{ Mean \% share in DM } \\
\hline & \multicolumn{2}{|c|}{ sowing } & \multicolumn{2}{|c|}{ planting } & \\
\hline & \multicolumn{4}{|c|}{$\mathrm{N}$} & \\
\hline 2016 & $23.30^{1, a}$ & \pm 0.71 & $22.55^{1, a}$ & \pm 0.78 & 2.28 \\
\hline 2017 & $15.99^{1, b}$ & \pm 1.32 & $15.77^{1, \mathrm{~b}}$ & \pm 0.39 & 1.59 \\
\hline 2018 & $13.30^{1, a}$ & \pm 0.19 & $12.59^{1, b}$ & \pm 0.07 & 1.27 \\
\hline Average of years & 17.53 & \pm 5.37 & 16.97 & \pm 5.09 & 1.71 \\
\hline \multicolumn{6}{|c|}{$P$} \\
\hline 2016 & $0.97^{1, a}$ & \pm 0.05 & $0.87^{\mathrm{A}, \mathrm{a}}$ & \pm 0.05 & 0.09 \\
\hline 2017 & $0.28^{1, b}$ & \pm 0.03 & $0.27^{\mathrm{A}, \mathrm{b}}$ & \pm 0.01 & 0.03 \\
\hline 2018 & $0.33^{1, b}$ & \pm 0.06 & $0.30^{\mathrm{A}, \mathrm{b}}$ & \pm 0.03 & 0.03 \\
\hline Average of years & 0.53 & \pm 0.39 & 0.48 & \pm 0.33 & 0.05 \\
\hline \multicolumn{6}{|c|}{$\mathrm{K}$} \\
\hline 2016 & $2.11^{1, a}$ & \pm 0.06 & $1.51^{11, a}$ & \pm 0.09 & 0.18 \\
\hline 2017 & $1.22^{1 . b}$ & \pm 0.16 & $0.99^{1, b}$ & \pm 0.13 & 0.11 \\
\hline 2018 & $1.33^{1, b}$ & \pm 0.01 & $1.21^{1, \mathrm{a}}$ & \pm 0.07 & 0.13 \\
\hline Average of years & 1.55 & \pm 0.49 & 1.23 & \pm 0.26 & 0.14 \\
\hline \multicolumn{6}{|c|}{$\mathrm{Mg}$} \\
\hline 2016 & $1.15^{1, \mathrm{a}}$ & \pm 0.26 & $0.88^{1, a}$ & \pm 0.09 & 1.02 \\
\hline 2017 & $0.43^{1, b}$ & \pm 0.01 & $0.52^{1, b}$ & \pm 0.01 & 0.47 \\
\hline 2018 & $0.71^{1, a}$ & \pm 0.03 & $0.73^{1, a}$ & \pm 0.01 & 0.72 \\
\hline Average of years & 0.76 & \pm 0.36 & 0.71 & \pm 0.18 & 0.74 \\
\hline \multicolumn{6}{|c|}{$S$} \\
\hline 2016 & $1.61^{1, a}$ & \pm 0.05 & $1.50^{1, a}$ & \pm 0.02 & 0.16 \\
\hline 2017 & $0.81^{1, b}$ & \pm 0.01 & $0.70^{1, b}$ & \pm 0.01 & 0.08 \\
\hline 2018 & $0.80^{1, b}$ & \pm 0.01 & $0.73^{1, b}$ & \pm 0.03 & 0.08 \\
\hline Average of years & 1.07 & \pm 0.46 & 0.98 & \pm 0.45 & 0.10 \\
\hline
\end{tabular}

* explanations of abbreviations: values marked with the same letters do not differ significantly according to the Tukey test at the significance level of $p=0.05$; Roman number - way of plantation establishment, lowercase year of sampling. 
element was recorded. In the second year of experiment, the decrease ranged from 36.6 to $41.2 \%$ and was statistically significant for the cultivation from sowing and planting, while in the third year it ranged from $19.9 \%$ to $34.4 \%$ and was statistically significant only for the cultivation from sowing. The magnesium content in the biomass of Virginia fanpetals as well as potassium depended on the age of the plantation (Table 2). The largest amounts of this macroelement were determined in the first year of establishment of the plantation from sowing and planting. In subsequent years, a downward trend in magnesium was recorded. Compared to the first year, the content of magnesium in the biomass of the test plant grown from sowing decreased in relation to the second and third years by 62.6 and $38.3 \%$, respectively, and planting - by 40.9 and $17.0 \%$, respectively. The highest sulfur content was characterized by the test plant biomass taken from both sowing and planting in the first year of cultivation. In subsequent years, a significant decrease of $50 \%$ in the content of this element was noted. In these years, the sulfur content in Virginia fanpetals biomass was around $0.80 \mathrm{~g} \cdot \mathrm{kg}^{-1} \mathrm{DM}$ for the plants grown from sowing and $0.70 \mathrm{~g} \cdot \mathrm{kg}^{-1} \mathrm{DM}$ from planting. It was found that the method of establishing the plantation did not have a clear and targeted effect on the content of magnesium and sulfur in the Virginia fanpetals biomass.

On the basis of the data provided by Kus and Matyka [2010], as well as Łąbętowicz and Stępień [2010] it can be stated that in our own research, the nitrogen content was ten times higher, phosphorus and sulfur twice higher, and phosphorus more than twice lower.

Increasing the content and greater uptake of macronutrients by the Virginia fanpetals biomass can be justified by the value of soil $\mathrm{pH}\left(\mathrm{pH}_{\mathrm{KCl}}\right)$ on the intensity of microbiological processes occurring in the soil. This is confirmed by the

Table 3. Sum of macronutrient uptake by Virginia fanpetals biomass in years 2016-2018

\begin{tabular}{|c|c|c|c|}
\hline \multirow{3}{*}{ Element } & \multicolumn{2}{|c|}{$\begin{array}{c}\text { Plantation establishment } \\
\text { system }\end{array}$} & \multirow{3}{*}{$\operatorname{LSD}_{0.05}$} \\
\hline & sowing & planting & \\
\hline & \multicolumn{2}{|c|}{ in $\mathrm{kg} \cdot \mathrm{ha}^{-1} \mathrm{DM}$} & \\
\hline Nitrogen & 267 & 315 & 6.78 \\
\hline Phosphorus & 5.82 & 6.92 & 0.03 \\
\hline Potassium & 23.3 & 24.3 & n.s. \\
\hline Magnesium & 10.5 & 13.9 & 0.15 \\
\hline Sulfur & 14.8 & 16.4 & 0.14 \\
\hline
\end{tabular}

results of the research obtained by Bielińska et al. [2008], Wysokińskiego and Kalembasy [2006], Gibczyńska et al.[2019] who found that as a result of these processes, the nutrients not yet available for plants are converted into the available forms, and therefore the plant is able to take them up.

The total uptake of macronutrients by the Virginia fanpetals biomass was higher in planting compared to sowing (Table 3). The statistical differences were proven for nitrogen, phosphorus, magnesium and sulfur, and for potassium, it was an insignificant difference.

While analyzing the dynamics of macronutrient uptake by the Virginia fanpetals biomass, it was found that in the first year it was definitely smaller and ranged from 4.88 to $16.47 \%$ (Figure 3). In the following years, the uptake increased, reaching the highest values up to $58 \%$ in the last year of research. Similar results were obtained by Iżewska [2009]. Absorption of macroelements by the Virginia fanpetals biomass depended on the yield and content of the elements discussed. It was also found that in the first year of plantation establishment, the dynamics of nitrogen, phosphorus, potassium, magnesium and sulfur uptake was were in the case of the Virginia fanpetals biomass from planting compared to sowing. An inverse relationship was noted in the subsequent years of running the plantation, except for the dynamics of potassium uptake.

Mineral fertilization introducing basic nutrients for plants was used in the experiment; therefore, the calculations regarding the correlation between the yield and calorific value as well as the moisture content and the yield and nitrogen, phosphorus and potassium uptake, were performed.

The research results indicate that the largest correlation occurred between the size of the Virginia fanpetals biomass yield (sowing, planting), as well as the nitrogen and phosphorus uptake, slightly less for potassium (Figure 4). The calculated correlation coefficients were: nitrogen $\mathrm{r}=0.977$, phosphorus $\mathrm{r}=0.971$ and potassium $\mathrm{r}=0.335$ [Kacoń 2005, Styrczula and Możdżer 2013]. A correlation analysis showed very high correlation between the size of the Virginia fanpetals biomass yield as well as the nitrogen and phosphorus uptake. This proves that nutrient uptake is heavily dependent on crop yields [Styrczula and Możdżer 2013, Gaj 2010].

The largest correlation occurred between the yield quantity of Virginia fanpetals from sowing and planting, and the calorific value and about 

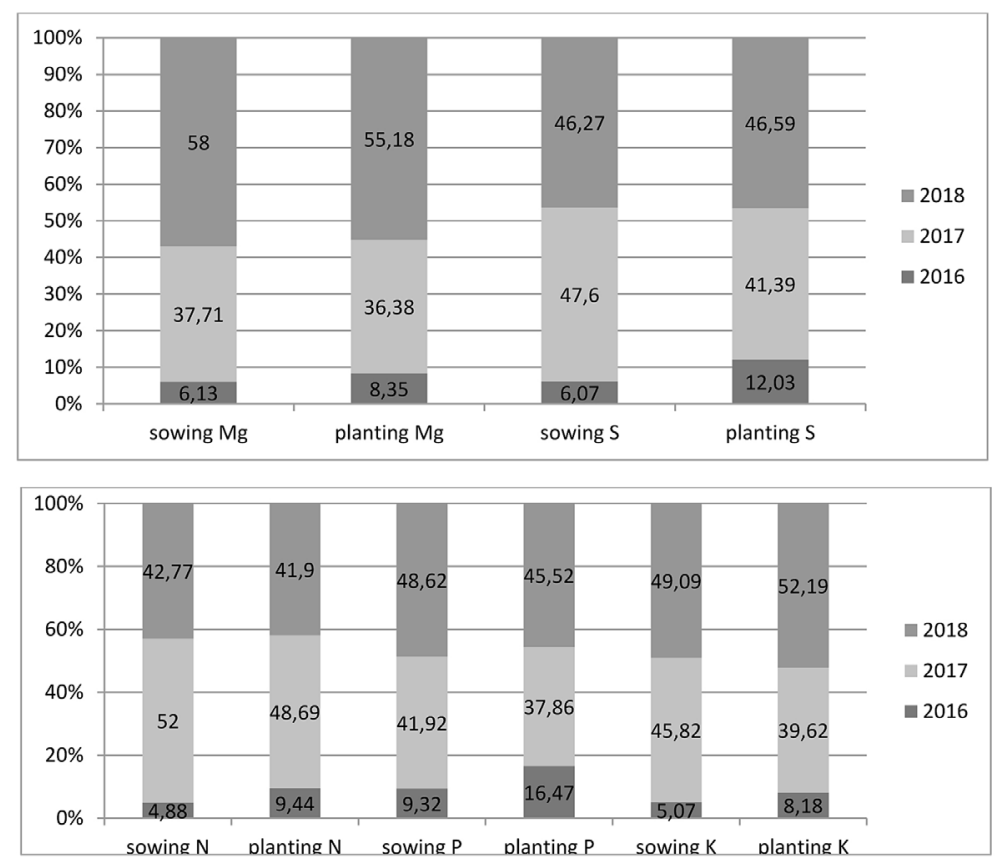

Fig. 3. Dynamics of macronutrient uptake by the Virginia fanpetals biomass depending on the cultivation system in 2016-2018 in relative numbers (total uptake $=100 \%$ )
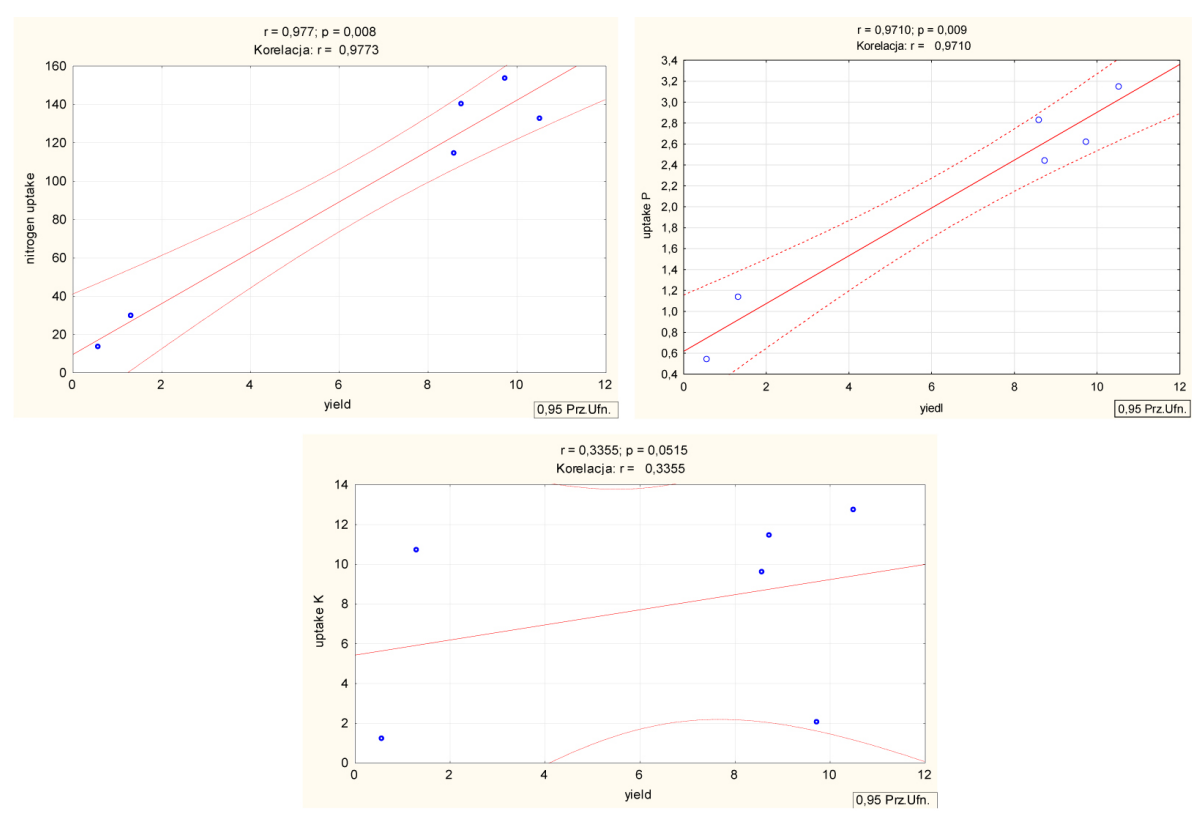

Fig. 4. Straight-line relationships between the yield quantity of the Virginia fanpetals and the uptake of nitrogen, phosphorus and potassium
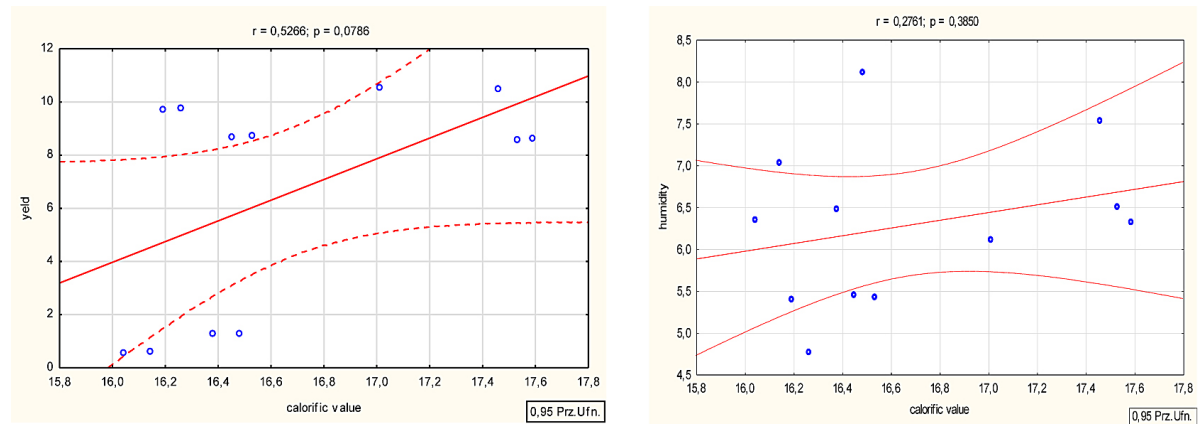

Fig. 5. Straight-line relationships between the calorific value of the Virginia fanpetals biomass and yield and moisture content 
$50 \%$ lower for humidity. The calculated correlation coefficients were for: yield $\mathrm{r}=0.526$ and moisture content $r=0.276$ (Figure 5).

During the experiment, the biomass yields were significantly positively correlated with the uptake of nitrogen, phosphorus and potassium by the test plant as well as the calorific value. Kocon [2005] reported similar research results. The calorific value of the Virginia fanpetals biomass with the analytical moisture content was also positively correlated.

\section{CONCLUSIONS}

1. Studies have shown that the method of establishing the plantation (sowing, planting) did not have any significant influence on the calorific value of Virginia fanpetals.

2. A significant effect on the calorific value of Virginia fanpetals was found between years. The lowest calorific value of the Virginia fanpetals biomass was obtained in the first year of plantation establishment, and the highest in the third year.

3. The method of the plantation establishing (sowing, planting) did not have any significant influence on the content of nitrogen, phosphorus and potassium in the biomass, and was significant for magnesium and sulfur.

4. More macroelements were contained in the Virginia fanpetals biomass from sowing compared to planting.

5. The content of macronutrients in the Virginia fanpetals biomass (average of three years of cultivation) was in the following series of decreasing values: $\mathrm{N}>\mathrm{K}>\mathrm{S}>\mathrm{Mg}>\mathrm{P}$.

6 . The total uptake of macroelements by the Virginia fanpetals biomass was higher in the planting cultivation system.

7. The dynamics of macronutrient uptake by the Virginia fanpetals biomass depended on the yield and their content. It was pointed out that in the first year of running a plantation from planting, there was greater dynamics of macronutrient uptake by the Virginia fanpetals biomass compared to the sowing system.

8. A correlation analysis showed very high correlation between the size of Virginia fanpetals biomass yield as well as the nitrogen and phosphorus uptake.
9. The largest correlation occurred between the quantity of biomass yield of Virginia fanpetals from sowing and planting, and calorific value and about $50 \%$ lower for the moisture content.

\section{Acknowledgements}

The study was carried out as part of the research project „Novel Pathways of Biomass Production: Assessing the Potential of Sida hermaphrodita and Valuable Timber Trees", akronim SidaTim, NCBiR in program ERA-NET Co-FUND FACCE SURPLUS/I/SidaTim/03/2016.

\section{REFERENCES}

1. Anderson E., Arundale R., Oladeinde A., Wycisło A. Voigt T. 2011. Growth and agronomy of Miscanthus $\mathrm{x}$ giganteus for biomass production. Biofuels, 2, 71-87.

2. Artyszak D. 2016. Energy crops - characteristics of basic species and their use in the Polish energy sector. Proceedings „Nowoczesna Energetyka Europy Środkowo-Wschodniej”, Warszawa, 1-34.

3. Bielińska. J., Futa B., Mocek A., 2008. Impact of agrotechnical operations on the functioning of the agricultural landscape. Inżynieria Rolnicza, 10(108), 7-15.

4. Biernat K. 2012. Prospects for the development of biofuel technologies in the world by 2050. Chemik, 66(11), 1178-1189.

5. Bocqueho G., Jacquet F. 2010. The adopition of switchgrass and miscanthus by farmers: Impact of liquidity constraints and risk preferences. Energy Policy, 38, 2598-2607.

6. Borkowska H., Lipiński W. 2008. Comparison of the content of selected elements in the biomass of Pennsylvanian mallow cultivated in soil conditions Acta Agroph. 11(3), 589-595.

7. Borkowska H., Molas R., Kupczyk A. 2009. Virginia Fanpetals (Sida hermaphrodita Rusby) Cultivated on Light Soil; Height of Yield and Biomass Productivity. Polish J. Environ. Stud., 18, 563-568.

8. Borkowska H., Molas R., Skiba D., Machaj D. 2016. Yielding and energy value of Pennsylvanian mallow depending on the level of nitrogen fertilization. Acta Agroph. 23(1), 5-14.

9. Bury M., Kitczak T., Możdżer E., Siwek H., Włodarczyk M., 2019. Cultivation of Sida (Pennsylvanian mallow). Production results, agrotechnics and utilization. Wyd. ZUT, 30-60.

10. Cosentino S., Scordia D., Testa G., Monti A., Alexopoulou E., Christou M. 2018. The Importance of Perennial Grasses as a Feedstock for Bioenergy and 
Bioproducts. Perenial Grasses for Bioenergy and Bioproducts, Elsevier: The Netherlands, 1-33.

11. Gaj R. 2010. Effect of different level of potassium fertilization on Winter oilseed rape nutritional status AT the initation of the main stem growth and on the field. Oilseed Crops XXXI, 115-124.

12. Gajewski R. 2016. Potential role of energy plantations in Poland. Polish Chamber of Biomass. Polska Izba Biomasy, Warszawa. http://www.econet-poland.pl/fileadmin/ahk_poleneconet/Publicationen/ Polska.

13. Gibczyńska M., Stankowski S., Hury G., Sobolewska M., 2019. Analysis of the content of macroelements in soil and seeds of winter rape (Brassica Napus Var. Napus) as a result of fertilization using two-component mineral fertilizers. Journal of Ecological Engineering, 20(4), 61-68. DOI: $10.12911 / 22998993 / 102703$

14. Iqbal Y., Lewandowski I. 2014. Biomass composition and ash melting behaviour of selected miscanthus genotypes in south Germany. FuelProcess. Technol., 121, 47-55.

15. Iżewska A., 2009. Suitability of municipal sewage sludge composts for fertilizing sugar Miscanthus (Miscanthus sacchariflorus Maxim.). Wyd. Zachodniopomorskiego Uniwersytetu Technologicznego w Szczecinie. Monografia, 1-24.

16. Jagustyn B., Bątorek-Giesa N., Wilk B. 2011. Assessment of biomass properties used for energy purposes. Chemik, 65, 6, 557-563.

17. Janowicz L. 2006. Biomass in Poland. Energetyka, 8: 601-604.

18. Kocoń A. 2005. Fertilization of spring and winter wheat, yield and quality of grain. Pam. Puł. 139, 57-64.

19. Kowalczyk-Juśko A. 2017.The Influence of the Ash from the Biomass on the Power Boiler Pollution. Journal of Ecological Engineering, 18(6), 200-204. DOI: 10.12911/22998993/76897

20. Kacprzak A., Michalska K., Romanowska-Duda Z., Grzesik M. 2012. Energy crops as a valuable raw material for biogas production. Kosmos. Prob. Nauk Biol., 2(61), 281-293.

21. Kalembasa S., Wiśniewska B. 2006. The influence of nitrogen doses on the biomass yield of Sida (Sida hermaphrodita Rusby) and its content of macroelements. Acta Agroph., 8(1), 127-138.

22. Kisiel A., Lewandowski I. 2017. Miscanthus as biogas substrate- cutting tolerance and potential for anaerobic digestion. GCB Bioenerg. 9, 153-167.

23. Kowalczyk-Juśko A. 2009. Ash from various energy crops. Proceedings of ECOpole, 3(1), 159-164.

24. Kuś J., Matyka M. 2010. Selected elements of agrotechnics of plants grown for energy purposes. [In:] Bocian P., Golec T, Rakowski J. (Eds.). Modern technologies for obtaining and energetic use of biomass.. Wyd. IE Warszawa, 101-120.

25. Lewandowski I., Clinton-Brown J., Trindade L.M., Linden V.D., Schwarz K.U., Muller-Samann K., Anisimov A., Chen C.-L., Dolstra O., Dommison I.S. 2016. Programs on Optimizing Biomass Production for the European Bioeconomy. Results of the EU FP7 Project OPTIMISC. Front. Plant Sci., 7, 1620.

26. Łabętowicz J., Stępień W. 2010. Fertilization of energy crops (willow, miscanthus, mallow). Modern technologies for obtaining and energetic use of biomass.. Instytut Energetyki, 89-100.

27. Mółka J., Łapczyńska-Kordon B. 2011. Energy properties of selected biomass species. Inż. Rol., 6 (131), 141-146.

28. Sapek A., Sapek B. 2012. The importance of biofuels in obtaining energy is renewed.. Woda-ŚrodowiskoObszary Wiejskie, 12 (37), 139-151.

29. Stanisławska-Glubiak E., Korzeniowska J. 2007. Assessment of plant nutritional status. . Oddział Krakowski Polskiego Towarzystwa Inżynierii Ekologicznej, Stacja Chemiczno- Rolnicza, 5-21.

30. Styrczula P., Możdżer E. 2013. Effect of multicompnent mineral fertilizers and organic fertilization on the NPK content and uptake by perennial rye-grass biomass Chemik 67(7), 604-615.

31. Regulation of the Minister of Environment (in Poland). Official Journal of low item. 1395 of 2016.

32. Van Valthuizen, H. 2003. Agroecological zoning of Europe. http://agrienv.irc.it/activities/pd.fs/irena/ Velthuizen-AEZ-Europe.pdf.

33. Wach E. 2007. Renewable energy sources until 2020 years. Czysta Energia, 4, 1-40.

34. Weiland P. 2010. Biogas production:current state and prespectives. Appl. Microbiol. Biotechnol., 85, 849-860.

35. Wiesenthal T. 2006. How mich bioenergy can Euro produce without harming enriroment. EEA Raport, 7-67.

36. Witzel C.-P., Finger R. 2016. Economic evaluation of Miscanthus production - A review. Renew/Sustain. Energy Rev., 56, 681-696.

37. Wysokiński A., Kalembasa S., 2006. Selected physicochemical properties of fresh and composting of sewage sludge and their mixtures with $\mathrm{CaO}$ or brown coal ash.. Acta Sci. Pol., Formatio Circumiectus, 1, 51-61.

38. Zub H.W., Brancourt-Hulmel M. 2010. Agronomic and physiological performances of different species of Miscanthus, a major Energy crop. Agron. Sustain. Dev. 30, 201-214. 